\title{
PENGARUH UKURAN PERUSAHAAN, PROFITABILITAS, KEBIJAKAN DIVIDEN, LEVERAGE DAN LIKUIDITAS TERHADAP NILAI PERUSAHAAN
}

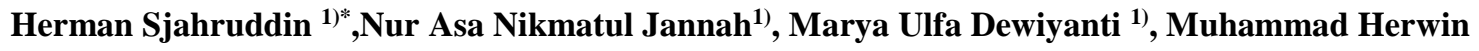 \\ Saputra $^{1)}$, Rusni Rusni ${ }^{1)}$ \\ 1) Program Studi Manajemen, Sekolah Tinggi Ilmu Ekonomi Makassar Bongaya \\ Email: herman.sjahruddin@stiem-bongaya.ac.id, nurasa398@gmail.com
}

\begin{abstract}
This study aims to examine the effect of firm size, profitability, dividend policy, leverage, and liquidity on firm value in the basic industry and chemical sub-sectors of the cement industry listed on the Indonesia Stock Exchange for the 2016-2019 period. This study uses a quantitative paradigm by utilizing three issuer's quarterly financial statements which were analyzed using linear regression. The results of the analysis provide evidence that leverage and liquidity have a significant negative effect on firm value, whereas firm size, profitability and dividend policy contribute positively but cannot increase the firm values.
\end{abstract}

Keywords : Dividend, leverage, liquidity, firms, profitability.

Article Information:

Received Date: 8 Oktober 2021

Revised Date: 1 November 2021

Accepted Date: 5 November 2021 


\section{PENDAHULUAN}

Nilai perusahaan merupakan salah instrumen keuangan terpenting yang digunakan oleh investor dalam mengambil keputusan berinvestasi pada perusahaan. Pernyataan tersebut dibuktikan pada salah satu sub sektor yang listing pada Bursa Efek Indonesia, yaitu sub sektor semen. Sub sektor tersebut untuk kurun waktu lima tahun terakhir mengalami permasalahan keuangan yang menyebabkan price book value emiten umumya berada pada posisi negatif, seperti yang ditunjukkan pada Gambar berikut:

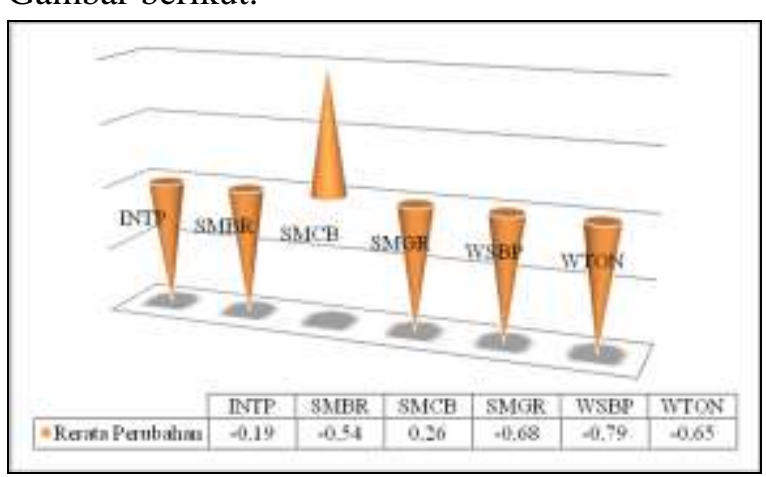

Sumber : idnfinancial.com (data diolah,2021)

Gambar 1. Rerata PBV Sub Sektor Semen

Gambar 1 memperlihatkan jika rerata perubahan nilai perusahaan sub sektor semen selama periode 2015-2019 berada pada nilai negatif, Berdasarkan report idnfinancial.com yang menyatakan jika harga saham sebagai cerminan PBV yang negatif diakibatkan karena industri ini mengalami oversupply dan adanya predatory pricing serta efektivitas keuangan yang belum optimal dalam pengelolaannya. PBV yang bertanda negatif tersebut menjadi permasalahan dalam studi ini.

Terdapat beberapa faktor keuangan yang memengaruhi PBV, seperti ukuran perusahaan. Ukuran perusahaan dapat terlihat dari total aset yang dimiliki oleh satu perusahaan. Ukuran perusahaan yang besar mencerminkan bahwa perusahaan tersebut sedang mengalami perkembangan dan pertumbuhan yang baik sehingga meningkatkan nilai dari suatu perusahaan.
Setiap kenaikan ukuran perusahaan suatu perusahaan yang diukur dengan $l n$ total assets berdampak pada peningkatan nilai suatu perusahaan yang diukur dengan Price to Book Value (PBV). Price to Book Value merupakan ratio pasar yang digunakan untuk mengukur kinerja harga pasar saham terhadap nilai buku (Astika et al., 2019c). PBV dirumuskan sebagai berikut :

$$
\mathrm{PBV}=\frac{\text { harga per lembar saham }}{\text { nilai buku pr lembar saham }} \times 100 \%
$$

Ukuran perusahaan merupakan cerminan total dari aset yang dimiliki suatu perusahan. dalam penelitian ini adalah ukuran perusahaan berpengaruh positif signifikan terhadap nilai perusahaan (Irawan \& Kusuma, 2019).

Pemilihan variabel profitabilitas dalam penelitian ini disebabkan karena jika emiten memiliki profitabilitas yang cukup tinggi maka emiten tersebut akan mendapatkan dana yang cukup proporsional dalam membiayai aktivis operasi, sehingga perusahaan dapat meningkatkan kinerjanya yang berakibat pada meningkatnya nilai perusahaan (Rudangga, 2016). Bukti riset terdahulu menunjukkan jika profitabilitas mempunyai efek yang positif pada nilai perusahaan (Martha et al,, 2018; Hertina et al.,2019; Indrayani et al., 2021).

Studi lainnya yang menguji dampak kebijakan dividen pada nilai perusahaan memperlihatkan hasil yang bervariasi seperti pada riset yang dilakukan Senata (2016). bahwa kebijakan dividen berpengaruh positif terhadap nilai perusahaan, sedangkan penelitian yang dilakukan Mayasari (2015) menyatakan sebaliknya bahwa kebijakan dividen berpengaruh negatif terhadap nilai perusahaan, kemudia pada riset yang dialakukan Martha et al. (2018) menunjukkan jika kebijakan dividen tidak berpengaruh terhadap nilai perusahaan.

Leverage merupakan rasio yang digunakan untuk menggambarkan bagaimana kemampuan suatu perusahaan dalam melunasi hutanghutang yang dimiliki perusahaan tersebut. Perusahaan mempunyai harapan dengan 
hutang yang dimilikinya, maka akan membantu perusahaan dalam mendanai dan mengelola aset yang dimiliki untuk mendapatkan laba sehingga nilai perusahaan akan semakin meningkat.

Hasil penelitian Vaneasa (2020) menemukan jika leverage berpengaruh positif terhadap nilai perusahaan, sedangkan riset yang dilakukan Dewi et al. (2014) menemukan hal yang sebaliknya, jika leverage berpengaruh negatif terhadap nilai perusahaan. Kemudian pada studi yang dilakukan Haryadi \& Nuraeni (2016) menemukan jika leverage tidak berpengaruh terhadap nilai perusahaan.

Tingkat likuiditas suatu perusahaan bukan berarti hal tersebut mampu mempengaruhi dividen yang dibagikan, hal ini dikarenakan perusahaan pada saat melakukan pembagian dividen tidak selalu memperhatikan keadaan utang lancarnya dan akan lebih fokus pada laba yang diperoleh perusahaan (Bahri, 2017 : Aryani \& Muliati, 2020).

\section{TINJAUAN PUSTAKA}

\section{Teori Sinyal}

Teori sinyal menjelaskan tentang bagaimana manajer memberikan sinyal kepada investor untuk mengurangi asimetri informasi melalui laporan keuangan. Laporan keuangan yang baik akan meningkatkan nilai perusahaan, apabila pada laporan keuangan yang disajikan perusahaan menyajikan profitabilitas perusahaan baik, pembayaran dividen yang relatif besar, menginformasikan biaya-biaya akuntansi lingkungan dan rasio likuiditas yang tinggi maka laporan keuangan perusahaan tersebut akan memberikan sinyal yang positif bagi para pengguna laporan keuangan khususnya investor (Anna et al.,2020; Sudarti et al., 2021).

Perusahaan mengharapkan dengan memberikan sinyal positif yang berupa hal-hal baik mengenai laporan keuangan akan memberikan gambaran atas kondisi perusahaan tersebut dan membuat pihak eksternal tertarik dan percaya untuk menanamkan modalnya kepada perusahaan (Awaluddin et al., 2020; Dewi \& Muliati, 2021).

\section{Pengaruh Ukuran Perusahaan Terhadap Nilai Perusahaan}

Ukuran perusahaan yang besar dan tumbuh dapat mencerminkan bahwa tingkat profit di masa mendatang akan semakin baik dan juga dapat mencerminkan perusahaan mempunyai komitmen yang tinggi untuk terus memperbaiki kinerjanya, sehingga pasar akan mau membayar lebih mahal untuk mendapatkan sahamnya karena percaya akan memperoleh pengembalian yang menguntungkan dari perusahaan tersebut dan hal itu menyebabkan nilai perusahaan meningkat (Maryam \& Mus, 2020). Ukuran perusahaan dihitung dengan logaritma natural dari total aset, adapun rumus untuk menghitung ukuran perusahaan (Suardana et al., 2020)

\section{Size $=$ Ln $($ Total Aset $)$}

Hasil empiris lainnya, menunjukkan jika ukuran perusahaan berpengaruh positif terhadap nilai perusahaan (Astika et al., 2019; Suardana et al., 2020). Berdasarkan hasil penelitian tersebut, maka dirumuskan hipotesis:

$\mathrm{H}_{1}$ : Ukuran perusahaan berpengaruh positif terhadap nilai perusahaan.

\section{Pengaruh Profitabilitas Terhadap Nilai Perusahaan}

Profitabilitas yang tinggi pada perusahaan maka semakin besar kemungkinan perusahaan untuk membagikan dividennya. Tentu saja hal ini dapat menarik minat investor untuk menanamkan modalnya di perusahaan sehingga akan meningkatkan nilai perusahaan (Putra \& Lestari, 2016). Profitabilitas yang dicapai perusahaan dapat dihitung dengan menggunakan perhitungan Return On Asset (ROA). (Indrayani et al., 2021).

$$
\text { ROA }=\frac{\text { laba bersih }}{\text { total aset }} \times 100 \%
$$

Beberapa peneliti memberikan bukti bahwa nilai perusahaan dipengaruhi secara positif oleh profitabilitas (Martha et al, 2018; Astika et al., 2019). Berdasarkan hasil tersebut, maka dirumuskan hipotesis:

$\mathrm{H}_{2}$ : Profitabilitas berpengaruh positif terhadap nilai perusahaan. 


\section{Pengaruh Kebijakan Dividen Terhadap Nilai Perusahaan}

Kebijakan dividen sering dianggap sebagai sinyal bagi investor dalam menilai baik buruknya perusahaan, karena kebijakan dividen dapat membawa pengaruh terhadap harga saham perusahaan. Pembayaran dividen yang relatif besar oleh perusahaan akan dianggap investor sebagai sinyal positif terhadap perkembangan perusahaan di masa yang akan datang, maka pembayaran dividen yang besar akan meningkatkan nilai perusahaan. Kebijakan Dividen dihitung dengan menggunakan perbandingan antara dividend dengan earning per share (Indrayani et al., 2021). secara matematis, indikator kebijakan dividen dapat dinyatakan sebagai berikut:

$$
\mathrm{DPR}=\frac{\text { dividen per share }}{\text { earning per share }} \times 100 \%
$$

Riset terdahulu menunjukkan bukti bahwa kebijakan dividen berpengaruh positif dan signifikan terhadap Nilai Perusahaan (Senata, 2016). Merujuk pada beberapa temuan riset terdahulu, maka dapat dirumuskan hipotesis sebagai berikut :

$\mathrm{H}_{3}$ : Kebijakan dividen berpengaruh positif terhadap nilai perusahaan.

\section{Pengaruh Leverage Terhadap Nilai Perusahaan}

Leverage yang tinggi, artinya pendanaan dengan utang semakin banyak, maka semakin sulit bagi perusahaan untuk memperoleh tambahan pinjaman karena dikhawatirkan perusahaan tidak mampu menutupi utangutangnya dengan aset yang dimilikinya. Perusahaan yang memiliki rasio utang yang lebih besar akan membagikan dividen lebih kecil karena laba yang diperoleh digunakan untuk melunasi kewajiban, hal tersebut akan membuat nilai perusahaan dimata investor juga menurun. Leverage diukur dengan menggunakan Debt to Asset Ratio (DAR). Adapun rumus yang digunakan dalam perhitungan Debt to Asset Ratio (DAR) (Kasmir, 2016:156) sebagai berikut :

$$
\mathrm{DAR}=\frac{\text { total kewajiban }}{\text { total aset }} \times 100 \%
$$

Temuan riset sebelumnya memberikan bukti bahwa leverage secara signifikan berpengaruh negatif terhadap nilai perusahaan.
(Nurhanimah et al., 2019). Merujuk pada beberapa temuan tersebut, , maka dirumuskan hipotesis sebagai berikut:

$\mathrm{H}_{4}$ : Leverage berpengaruh negatif terhadap nilai perusahaan.

\section{Pengaruh Likuiditas Terhadap Nilai Perusahaan}

Likuiditas dianggap berpengaruh terhadap nilai perusahaan karena semakin tinggi rasio likuiditas, maka semakin besar kemungkinan hutang bisa dibayar dan sebaliknya semakin kecil rasio likuiditas, semakin kecil kemungkinan hutang bisa dibayar. Perusahaan dengan rasio likuiditas yang besar akan menyebabkan harga saham dari perusahaan tersebutjuga akan meningkat, hal ini menyebabkan nilai perusahaan juga akan meningkat. Likuiditas diukur dengan menggunakan current ratio (CR) semakin besar aktiva lancar dan hutang lancar, maka semakin tinggi kemampuanperusahaan dalam memenuhi kewajiban (hutang) jangka pendek (Oktaviarni et al., 2019)

$$
\text { Current Ratio }=\frac{\text { aset lancar }}{\text { hutang lancar }} \times 100 \%
$$

Beberapa peneliti berhasil membuktikan jika likuiditas berpengaruh positif terhadap nilai perusahaan (Andriani \& Rudianto, 2019). Temuan riset tersebut digunakan untuk merumuskan hipotesis, sebagai berikut : $\mathrm{H}_{5}$ : Likuiditas berpengaruh positif terhadap nilai perusahaan.

\section{METODE PENELITIAN}

Studi ini berbasis paraadigma kuantitatif menggunakan data laporan keuangan secara kuartal dari tiga emiten (INTP, SMGR, \& WTON), hal ini disebabkan karena emiten lainnya, yaitu: SMBR, SMCB \& WSBP penyajian laporan keuangan (kuartal) tidak disajikan secara lengkap (yang merupakan perusahaan sektor industri dasar dan kimia pada sub sektor semen yang terdaftar di Bursa Efek Indonesia periode 2016-2019 dengan mengakses www.idnfinancial.com Teknik sampling criteria digunakan, sehingga diperoleh keseluruhan unit data analisis berjumlah 36 unit data yang dianalisis dengan menggunakan regresi liner berganda. 


\section{HASIL DAN PEMBAHASAN \\ Deskripsi variabel}

Penelitian ini menggunakan lima variabel bebas dan satu variabel terikat, berikut disajikan deskripsi variabel analisis:

Tabel 1. Deskripsi variabel

\begin{tabular}{|l|c|c|}
\hline Variabel & Mean & Std. Deviation \\
\hline PBV & -20.5556 & 67.70585 \\
\hline UP & 484.3889 & 54.17447 \\
\hline PROF & 15.5556 & 5.87218 \\
\hline KDIV & 132.7778 & 64.58930 \\
\hline LVRG & 58.1667 & 17.65624 \\
\hline LKTS & 147.1111 & 49.92839 \\
\hline
\end{tabular}

Sumber : Data diolah (2021)

Deskripsi variabel menunjukkan jika nilai mean pada PBV < Std. Dev. dan untuk UP, PROF, KDIV, LVRG dan KLTS > dibandingkan dengan nilai Std. Dev. Dominannya data variabel yang nilainya > Std. Dev., sehigga secara keseluruhan dinyatakan jika data cenderung berdistribusi secara normal.

\section{Pengujian Asumsi}

Asumsi klasik atau yang juga disebut dengan uji BLUE (best, linear, unbiassed, estimated) merupakan persyaratan yang wajib dipenuhi pada penggunaan analisis regresi. Secara satupersatu dapat ditunjukkan sebagai berikut;

\section{Pengujian kenormalan Data}

Tabel 2. Normalitas data

\begin{tabular}{|c|c|c|}
\hline Model & t-score & p-value \\
\hline KS-Test & 0,091 & 0,200 \\
\hline
\end{tabular}

Sumber : Data diolah (2021)

Tabel 2. hasil pengujian Kolmogorov-Smirnov, nilai jika nilai Test Statistic $=0,091>0,05$ dan $\mathrm{p}$-value $=0,200>0,05$. Hasil tersebut membuktikan jika data yang digunakan pada studi ini memenuhi kenormalan data.

\section{Pengujian multikol}

Tabel 3. Multikol data

\begin{tabular}{|l|c|c|}
\hline \multicolumn{1}{|c|}{ Efek } & Toll. < 1 & VIF < 10 \\
\hline UP $\rightarrow$ PBV & 0.060 & 6.603 \\
\hline PROF $\rightarrow$ PBV & 0.230 & 4.350 \\
\hline
\end{tabular}

\begin{tabular}{|l|l|l|}
\hline $\mathrm{KDIV} \rightarrow \mathrm{PBV}$ & 0.214 & 4.676 \\
\hline LVRG $\rightarrow$ PBV & 0.062 & 6.094 \\
\hline LKTS $\rightarrow$ PBV & 0.147 & 6.795 \\
\hline
\end{tabular}

Sumber : Data diolah (2021)

Tabel 3. Menunjukkan jika nilai Tollerance pada keseluruhan variabel bebas menunjukkan nilai $<1$ dan untuk nilai VIF $<10$., sehingga demikian dapat dinyatakan tidak terjadi multikolinearitas.

\section{Pengujian Autokorelasi}

Tabel 4. Autokorelasi

\begin{tabular}{|c|c|}
\hline Parameter & Hasil \\
\hline DW & 2,844 \\
\hline DU & 15,805 \\
\hline DL & 13,325 \\
\hline
\end{tabular}

Sumber : Data diolah (2021)

Tabel 4. menujukkan nilai Durbin Watson Test sebesar 2,044 pada presisi 0.05 atau 5\%, unit data $=36(\mathrm{n})$ dan $(\mathrm{k}=5)$ maka hasil $\mathrm{dL}=$ 1,1755 serta dU 1,799, 4-Du $=2.825$. Hasil tersebut menunjukan tidak ada auto korelasi dibuktikan dengan nilai du atau durbin upper 2,201 yang lebih kecil dari nilai DW sebesar 2,844 .

\section{Heterokedastisitas}

Pengujian keseragaman data, dapat ditujukkan pada hasil berikut:

Tabel 5. Heterokedasitas

\begin{tabular}{|c|c|c|r|c|c|}
\hline \multicolumn{2}{|c|}{$\begin{array}{c}\text { Kausalitas } \\
\text { (Glejser test) }\end{array}$} & $\begin{array}{c}\text { P- } \\
\text { value }\end{array}$ & $\begin{array}{c}\text { Sim } \\
\text { bol }\end{array}$ & $\begin{array}{c}\text { P- } \\
\text { level }\end{array}$ \\
\hline UP & $\rightarrow$ & PBV & -.536 & $>$ & 0,05 \\
\hline PROF & $\rightarrow$ & PBV & $\begin{array}{r}- \\
1.026\end{array}$ & $>$ & 0,05 \\
\hline KDIV & $\rightarrow$ & PBV & $\begin{array}{r}- \\
1.476\end{array}$ & $>$ & 0,05 \\
\hline LVRG & $\rightarrow$ & PBV & - & $>$ & 0,05 \\
\hline LKTS & $\rightarrow$ & PBV & .653 & $>$ & 0,05 \\
\hline
\end{tabular}

Sumber : Data diolah (2021)

Pada Tabel 5. nilai Glejser Test menunjukkan bahwa semua variabel dengan nilai $\mathrm{p}$-value > 0,05 , sehingga penggunaan data terbebas dari homedastisitas. 


\section{Analisis Regresi Ganda}

Tabel 6. Regresi Berganda

\begin{tabular}{|c|c|l|c|}
\hline \multicolumn{3}{|c|}{ Kausalitas } & $\begin{array}{c}\text { Un \& Std. } \\
\text { Coefficients } \\
\text { (Beta) }\end{array}$ \\
\hline \multicolumn{3}{|c|}{ (Constant) } & 94,951 \\
\hline \multicolumn{3}{|c|}{ Std. Error } & 336,808 \\
\hline UP & $\rightarrow$ & PBV & 0,439 \\
\hline PROF & $\rightarrow$ & PBV & 0,292 \\
\hline KDIV & $\rightarrow$ & PBV & 0,414 \\
\hline LVRG & $\rightarrow$ & PBV & $-1,415$ \\
\hline LKTS & $\rightarrow$ & PBV & $-0,881$ \\
\hline
\end{tabular}

Sumber : Data diolah (2021)

Hasil formulasi regresi penggunaannya pada studi ini menggunakan nilai unstandardized untuk menentukan persamaan regresi, berikut ditampilkan hasilnya:

$$
\begin{array}{ll}
\mathrm{Y}_{(\mathrm{PBV})} & 94,951_{\text {(konstanta) }}+0,439_{(\mathrm{UP})}+0,292 \\
& (\mathrm{PROF})+0,414_{(\mathrm{KDIV})}+-1,415_{(\mathrm{LVRG})}+ \\
& -0,881_{(\mathrm{LKTS})}+336,808_{(\mathrm{e})}
\end{array}
$$

Nilai konstanta bersimbolkan positive $=94,95$, ini menunukkan bahwa jika terjadi kenaikan sebesar 94,95\% maka kenaikan tersebut akan dikuti dengan kenaikan pada variabel lainnya dengan besaran yang sama. Hasil koefisien UP bertanda positif yaitu sebesar 0,439 mengungkapkan jika setiap penambahan sebesar 1\% maka akan meningkatkan PBV sebesar 0,439. koefisien PROF bertanda positif yaitu sebesar 0, 292 mengungkapkan jika setiap penambahan sebesar $1 \%$ maka akan meningkatkan PBV sebesar 0,292. Koefisien KDIV bertanda positif yaitu sebesar 0,414 mengungkapkan jika setiap penambahan sebesar 1\% maka akan meningkatkan PBV sebesar 0,414 , ketika faktor yang berbeda tetap ada (konstan).

Nilai negative ditunjukkan pada Koefisien LVRG yang bertanda negatif yaitu sebesar 1,415 mengungkaapkan jika setiap pengurangan sebesar $1 \%$ maka akan menurunkan PBV sebesar -1,415. Koefisien LKTS yang bertanda negatif yaitu sebesar 0,881 mengungkaapkan jika setiap pengurangan sebesar 1\% maka akan menurunkan PBV sebesar $-0,881$, ketika faktor yang berbeda tetap ada (konstan).

\section{Analisis Kelayakan Model}

Tahapan berikutnya dalam regresi, yaitu memastikan apakah formulasi pemodelan yang dibangun telah memenuhi kesesuaan ataupu tidak, regresi mensyaratkan jika data yang digunakan memenuhi keseuaian model, untuk

\begin{tabular}{|c|c|c|c|c|c|c|}
\hline \multicolumn{3}{|c|}{ Kausalitas } & F-hit. & Simbol & F-tab. & $\begin{array}{c}\mathrm{p}- \\
\text { value }\end{array}$ \\
\hline UP & $\rightarrow$ & PBV & \multirow{5}{*}{5.993} & $>$ & \multirow{5}{*}{2,533} & \multirow{5}{*}{0,001} \\
\hline PROF & $\rightarrow$ & PBV & & $>$ & & \\
\hline KDIV & $\rightarrow$ & PBV & & $>$ & & \\
\hline LVRG & $\rightarrow$ & PBV & & $>$ & & \\
\hline LKTS & $\rightarrow$ & PBV & & $>$ & & \\
\hline
\end{tabular}
itu ditunjukkan hasilnya, sebagai berikut:

Tabel 7. Kelayakan Pemodelan

Sumber : Data diolah (2021)

Tabel 7. hasil pengujian fisher test, menunjukkan jika nilai F-hitung sebesar 5.993 dan nilai $\mathrm{F}_{\text {-tabel }}$ sebesar 2.533 hasil tersebut menunjukkan bahwa nilai $\mathrm{F}_{\text {-hitung }}>\mathrm{F}_{\text {-tabel }}$ sehingga dapat dinyatakan bahwa model regresi dinyatakan layak.

\section{Analisis Determinasi}

Efek kontribusi pemodelan digunakan untuk mengetahui besaran kontribusi UP, PROF, KDIV, LVRG dan LKTS $\rightarrow$ PBV, untuk itu diperlihatkan pada tabel berikut:

Tabel 8, Kontribusi $\left(\mathrm{R}^{2}\right)$

\begin{tabular}{|c|c|}
\hline $\mathrm{R}$ & $\mathrm{R}$-square \\
\hline 0,707 & 0,500 \\
\hline
\end{tabular}

Sumber : Data diolah (2021)

Efek kontribusi ukuran perusahaan (UP), profitabilitas (PROF), kebijakan dividen (KDIV), leverage (LVRG), dan likuiditas (LKTS) sebesar $0,707 \times 0,707=0,500$ atau sebesar $50 \%$. 


\section{Uji Hipotesis}

Tabel 9. Student-test

\begin{tabular}{|l|c|c|}
\hline \multicolumn{1}{|c|}{ Efek } & $\begin{array}{c}\mathrm{t}- \\
\text { statistik }\end{array}$ & Probability \\
\hline $\mathrm{UP} \rightarrow \mathrm{PBV}$ & 0.835 & 0.410 \\
\hline PROF $\rightarrow$ PBV & 1.085 & 0.287 \\
\hline KDIV $\rightarrow$ PBV & 1.482 & 0.149 \\
\hline LVRG $\rightarrow$ PBV & -2.732 & 0.010 \\
\hline LKTS $\rightarrow$ PBV & -2.618 & 0.014 \\
\hline
\end{tabular}

Sumber : Data diolah (2021)

\section{Pengaruh Ukuran Perusahaan terhadap Nilai Perusahaan}

Hipotesis pertama menyatakan bahwa ukuran perusahaan berpengaruh positif terhadap nilai perusahaan. Berdasarkan hasil analisis uji regresi ditemukan bahwa ukuran perusahaan berpengaruh positif tidak signifikan terhadap nilai perusahaan karena investor membeli saham sebuah perusahaan tidak hanya ditinjau dari seberapa besar aset perusahaan namun juga dari sisi laporan keuangan, nama baik dan juga kebijakan dividen (Indrayani et al., 2021)

\section{Pengaruh Profitabilitas terhadap Nilai Perusahaan}

Hipotesis kedua menyatakan bahwa profitabilitas berpengaruh positif tidak signifikan terhadap nilai perusahaan. karena semakin besar profitabilitas maka nilai perusahaan yang diperoleh juga semakin besar. Perusahaan yang memiliki profitabilitas yang cukup tinggi akan mendapatkan dana yang cukup, sehingga perusahaan dapat meningkatkan kinerjanya yang berakibat pada meningkatnya nilai perusahaan (Rudangga, 2016). Hasil penelitian ini memiliki kesamaan dengan hasil studi yang dilakukan peneliti lainnya, bahwa profitabilitas mempunyai pengaruh yang positif signifikan terhadap nilai perusahaan (Indrayani et al., 2021).

\section{Pengaruh Kebijakan Dividen terhadap Nilai Perusahaan}

Hipotesis ketiga menyatakan bahwa kebijakan dividen berpengaruh positif tidak signifikan terhadap nilai perusahaan. Berdasarkan hasil analisis uji regresi ditemukan bahwa kebijakan dividen berpengaruh positif tidak signifikan terhadap nilai Perusahaan. Hasil riset ini mendukung temuan peneliti lainnya bahwa kebijakan dividen mempunyai pengaruh yang positif tidak signifikan terhadap nilai perusahaan (Indrayani et al., 2021; Yuniastri et al., 2021)

\section{Pengaruh Leverage terhadap Nilai Perusahaan}

Hipotesis keempat menyatakan bahwa leverage berpengaruh negatif signifikan terhadap nilai perusahaan. Hal ini di akibatkan perusahaan dalam mendanai asetnya cenderung menggunakan modal sendiri (internal financing) yang berasal dari laba ditahan dan modal saham daripada menggunakan hutang. Kecukupan dana yang dimiliki perusahaan untuk membiayai asetnya yang diperoleh dari modal sendiri membuat perusahaan mengurangi proporsi hutangnya. Hasil penelitian ini bertentangan dengan temuan Indrayani et al., (2021) bahwa leverage berpengaruh positif tidak signifikan terhadap nilai perusahaan.

\section{Pengaruh Likuiditas terhadap Nilai Perusahaan}

Hipotesis kelima menyatakan bahwa likuiditas berpengaruh negatif signifikan terhadap nilai perusahaan. Hal ini diakibatkan karena rasio likuiditas yang rendah menunjukkan adanya dana yang menganggur pada perusahaan tetapi rasio likuiditas yang rendah juga kurang bagus karena menunjukkan terjadinya masalah dalam likuidasi, namun para investor tidak memperdulikan tinggi rendahnya rasio likuiditas dalam perusahaan karena fokus para investor adalah pada kemampuan perusahaan menghasilkan laba. Para investor juga kurang tertarik pada rasio likuiditas karena 
menyangkut tentang kondisi internal suatu perusahaan dalam memenuhi kewajiban jangka pendeknya. Hasil penelitian ini memiliki perbedaan dengan temuan .Dewi \& Muliati (2021) bahwa likuiditas mempunyai pengaruh yang positif signifikan terhadap nilai perusahaan.

\section{KESIMPULAN DAN SARAN}

Ukuran perusahaan yang besar dalam pelaksanaannya tidak dapat menjadi penentu peningkatan nilai perusahaan karena investor membeli saham sebuah perusahaan tidak hanya ditinjau dari seberapa besar aset perusahaan namun juga dari sisi laporan keuangan, nama baik dan juga kebijakan dividen yang dibayarkan perusahaan. Profitabilitas yang tinggi tidak dapat mendorong meningkatnya nilai perusahaan. karena semakin besar profitabilitas maka semakin tinggi kinerja keuangan perusahaan, namun kondisi tersebut tidak serta merta mendorong peningkatan nilai. Kebijakan dividen yang tinggi tidak dapat meningkatkan nilai perusahaan, walaupun pembayaran dinaikkan untuk dibagikan kepada pemegang saham, hal tersebut tidak menjadi alasan dalam pen ingkatan nilai perusahaan.

Leverage yang rendah terbukti dapat meningkatkan nilai perusahaan, Perusahaan dalam mendanai asetnya cenderung menggunakan modal sendiri (internal financing) yang berasal dari laba ditahan dan modal saham daripada menggunakan hutang. Kecukupan dana yang dimiliki perusahaan untuk membiayai asetnya yang diperoleh dari modal sendiri membuat perusahaan mengurangi proporsi hutangnya. Likuiditas yang rendah terbukti meningkatkan nilai perusahaan, rendahnya likuiditas menunjukan adanya dana yang menganggur pada perusahaan tetapi rasio likuiditas yang rendah juga kurang bagus karena menunjukan terjadinya masalah dalam likuidasi, namun para investor tidak memperdulikan tinggi rendahnya rasio likuiditas dalam perusahaan karena fokus para investor adalah pada kemampuan perusahaan menghasilkan laba.

\section{REFERENSI}

Andriani, P. R., \& Rudianto, D. (2019). Pengaruh Tingkat Likuiditas, Profitabilitas dan Leverage Terhadap Nilai Perusahaan pada Subsektor Makanan dan Minuman yang Tercatat di BEI (BEI) Periode 2010-2017. Journal of Entrepreneurship, Management and Industry (JEMI), 2(1), 48-60.

Anita, A., \& Yulianto, A. (2016). Pengaruh Kepemilikan Manajerial Dan Kebijakan Dividen Terhadap Nilai Perusahaan. Management Analysis Journal, 5(1).

Anna, N., Ridjal, S., \& Sjahruddin, H. (2020). Implementasi Financial Projection Sebagai Strategi Pengelolaan Keuangan. Jurnal Ekonomi dan Bisnis Dharma Andalas, 22(2), 302-314.

Aryani, N. K. D., \& Muliati, N. K. (2020). Pengaruh Financial Distress, Asimetri Informasi, Ukuran Perusahaan Dan Leverage Terhadap Konservatisme Akuntansi Pada Perusahaan Manufaktur di Bursa Efek Indonesia (BEI) Periode Tahun 2014-2018. Hita Akuntansi dan Keuangan, 1(2), 572-601.

Astika, I. G., Suryandari, N. N. A., \& Putra, G. B. B. (2019). Pengaruh Profitabilitas, Kebijakan Dividen Dan Ukuran Perusahaan Terhadap Nilai Perusahaan Pada Perusahaan Manufaktur Yang Terdaftar Di Bursa Efek Indonesia (Bei) Periode 2015-2018. In Seminar Nasional Inovasi dalam Penelitian Sains, Teknologi dan Humaniora-InoBali 574585.

Awaluddin, A., Sjahruddin, H., Tadjo, M., \& Pascawati, P. N. S. (2020). Efek kontribusi struktur kepemilikan dan keputusan pendanaan dalam meningkatkan nilai perusahaan. $E$ Mabis: Jurnal Ekonomi Manajemen dan Bisnis, 21(2), 96-104.

Azizah, D. G., \& Widyawati, D. (2021). Pengaruh Kinerja Keuangan Dan Ukuran Perusahaan Terhadap Nilai Perusahaan Pada Perusahaan Food and Beverages di BEI. Jurnal Ilmu dan Riset Akuntansi (JIRA), 10(1). 
Bahri, Z. (2017). Analisis Sumber dan Penggunaan Modal Kerja Dalam Pengendalian Tingkat Likuiditas Perusahaan Pada UD Sofi Jaya Kota Probolinggo. Jurnal Ilmiah Ecobuss, 5(2), 41-52.

Brigham \& Houston. (2017). Dasar-Dasar Manajemen Keuangan. Salemba. Empat. Jakarta.

Dewi, N. K. M. A., \& Muliati, N. K. (2021). Pengaruh profitabilitas, ukuran perusahaan dan likuiditas terhadap kebijakan dividen. Hita Akuntansi dan Keuangan, 2(2), 359-377.

Dewi, P. Y. S., Yuniarta, G. A., AK, S., Atmadja, A. T., \& SE, A. (2014). Pengaruh struktur modal, pertumbuhan perusahaan dan profitabilitas terhadap nilai perusahaan pada perusahaan LQ 45 di BEI periode 2008-2012. JIMAT (Jurnal Ilmiah Mahasiswa Akuntansi) Undiksha, 2(1).

Dirganpratiwi, P., \& Yuniati, T. (2021). Pengaruh Profitabilitas, Leverage Dan Likuiditas Terhadap Nilai Perusahaan Pada Perusahaan Food and Beverage Yang Terdaftar Di BEI. Jurnal Ilmu dan Riset Manajemen (JIRM), 10(4).

Harahap, Sofyan Syafri. (2015). Analisis Kritis atas Laporan Keuangan. Edisi 10. Rajawali Pers, Jakarta.

Haryadi, R. M., \& Nuraeni, E. A. L. (2016). Pengaruh Leverage, Profitability, Market Value dan Ukuran Perusahaan terhadap Nilai Perusahaan Property yang Terdaftar di Bei Tahun 2012-2014. Ekonomia, 5(3), 59718.

Hertina, D., Hidayat, M. B. H., \& Mustika, D. (2019). Ukuran Perusahaan, Kebijakan Hutang Dan Profitabilitas Pengaruhnya Terhadap Nilai Perusahaan. Jurnal Ecodemica, 3(1), 1-10.

Indrayani, N. K., Endiana, I. D. M., \& Pramesti, I. G. A. A. (2021). Pengaruh Ukuran Perusahaan, Profitabilitas, Kebijakan Dividen, Akuntansi Lingkungan, Leverage Dan Likuiditas Terhadap Nilai Perusahaan. Kumpulan Hasil Riset Mahasiswa Akuntansi (KHARISMA), 3(1), 52-62.

Irawan, D., \& Kusuma, N. (2019). Pengaruh Struktur Modal Dan Ukuran Perusahaan Terhadap Nilai Perusahaan. Jurnal Aktual, 17(1), 66-81.
Kasmir, (2016). Analisis Laporan Keuangan. Jakarta : PT. RajaGrafindo Persada.

Martha, L., Sogiroh, N. U., Magdalena, M., Susanti, F., \& Syafitri, Y. (2018). Profitabilitas dan kebijakan dividen terhadap nilai perusahaan. Jurnal Benefita, 3(2), 227-238.

Maryam, S., \& Mus, A. R. (2020). Pengaruh Ukuran Perusahaan, Pertumbuhan Perusahaan, Likuiditas, Profitabilitas dan Kebijakan Dividen Terhadap Nilai Perusahaan. CESJ: Center Of Economic Students Journal, 3(1), 90-109.

Mayasari, A. S. (2015). Analisis Kebijakan Dividen, Kebijakan Utang Dan Nilai Perusahaan Pada Perusahaan Sektor Pertambangan Yang Terdaftar Di Bursa Efek Indonesia (BEI) Periode 20092013. Universitas Negeri Jember. Repository.

Nurhanimah, N., Anugerah, R., \& Ratnawati, V. (2019). Pengaruh Earnings Management dan Tax Avoidance terhadap Nilai Perusahaan dengan Struktur Kepemilikan sebagai Moderating Variable pada Perusahaan Kelompok LQ-45 di BEI Tahun 20132016. Journal of Applied Business Administration, 3(1), 1-13.

Oktaviarni, F., Murni, Y., \& Suprayitno, B. (2019). Pengaruh Profitabilitas, Likuiditas, Leverage, Kebijakan Dividen, dan Ukuran Perusahaan terhadap Nilai Perusahaan. Jurnal Akuntansi, 9(1), 1-16.

Putra, A. N. D. A., \& Lestari, P. V. (2016). Pengaruh kebijakan dividen, likuiditas, profitabilitas dan ukuran perusahaan terhadap nilai perusahaan. Doctoral dissertation, Udayana University.

Rudangga, I. G. N. G., \& Sudiarta, G. M. (2016). Pengaruh ukuran perusahaan, leverage, dan profitabilitas terhadap nilai perusahaan. Doctoral dissertation, Udayana University.

Senata, M. (2016). Pengaruh kebijakan dividen terhadap nilai perusahaan yang tercatat pada indeks LQ-45 Bursa Efek Indonesia. Jurnal Wira Ekonomi Mikroskil: JWEM, 6(1), 73-84.

Setiawan, M. R., Susanti, N., \& Nugraha, N. M. (2021). Pengaruh Struktur Modal, Perputaran Modal Kerja, dan Ukuran Perusahaan Terhadap Nilai 
Perusahaan. Owner: Riset Dan Jurnal Akuntansi, 5(1), 208-218.

Suaidah, Y. M. (2018). Pengaruh Pengungkapan Akuntansi Lingkungan dan Kepemilikan Saham Terhadap Nilai Perusahaan Melalui Kinerja Keuangan. JAD: Jurnal Riset Akuntansi dan Keuangan Dewantara, 1(2), 105116.

Suardana, I. K., Endiana, I. D. M., \& Arizona, I. P. E. (2020). Pengaruh Profitabilitas, Kebijakan Utang, Kebijakan Dividen, Keputusan Investasi, Dan Ukuran Perusahaan Terhadap Nilai Perusahaan. Kumpulan Hasil Riset Mahasiswa Akuntansi (KHARISMA), 2(2), 137-155.

Sudarti, S., Sjahruddin, H., Themba, O. S., \& Halim, A. (2020). Pengaruh Current Ratio, Return On Asset Dan Equity Pada Modal Kerja. E-Mabis: Jurnal Ekonomi Manajemen dan Bisnis, 21(2), 87-95.

Vanessa, M. (2020). Pengaruh Profitabilitas, Likuiditas, Pertumbuhan Perusahaan dan Struktur Modal Terhadap Nilai Perusahaan (Studi Empiris pada Perusahaan Manufaktur Sektor Industri Barang Konsumsi yang Terdaftar di Bursa Efek Indonesia Tahun 20162018). Doctoral dissertation, Universitas Multimedia Nusantara.

Yanti, N. L. E. K., Endiana, I. D. M., \& Pramesti, I. G. A. A. (2021). Pengaruh Ukuran Perusahaan, Ukuran Dewan Komisaris, Kepemilikan Institusional, Leverage, Dan Profitabilitas Terhadap Pengungkapan Corporate Social Responsibility. Kumpulan Hasil Riset Mahasiswa Akuntansi (KHARISMA), 3(1), 42-51.

Yuniastri, N. P. A., Endiana, I. D. M., \& Kumalasari, P. D. (2021). Pengaruh Profitabilitas, Kebijakan Dividen, Keputusan Investasi, Struktur Modal Dan Ukuran Perusahaan Terhadap Nilai Perusahaan Pada Perusahaan Manufaktur Yang Terdaftar Di Bursa Efek Indonesia Periode 20172019. KARMA (Karya Riset Mahasiswa Akuntansi), 1(1), 69-79. 